\title{
The Effect of Management Control System and Leadership Style on Managerial Performance (An Empirical Studies on SOE Company in Bandung)
}

\author{
Paulus Sugianto Yusuf ${ }^{1 *}$, Mohd Haizam Mohd Saudi ${ }^{1}$, Tiara Nurmalasari ${ }^{1}$, Nur Surayya Mohd Saudi ${ }^{2}$ \\ ${ }^{1}$ Widyatama University, Bandung, Indonesia \\ ${ }^{2}$ National Defense University of Malaysia \\ *Corresponding author E-mail: paulus.sugianto@widyatama.ac.id
}

\begin{abstract}
The purpose of this study is to determine the effect of management control system and leadership style on managerial performance using explanatory. Unit of analysis of this study is the managers who work in state-owned companies manufacturing in Bandung. Populations of this study are the employees who officiate as a manager in state-owned companies in Bandung and who became the sample of this study are 109 managers. The results of this study indicate that there are significant simultaneously effect between management control system and leadership style on managerial performance. Partially management control system has positive influence on managerial performance, as well as the leadership style which is partially positive influence on managerial performance.
\end{abstract}

Keywords: Management Control System; Leadership Style; Managerial Performance.

\section{Introduction}

According to [27], the first page "State-Owned Enterprises are business entities that all or most of their capital is owned by the state through direct investments from separated state assets". SOEs have a purpose to make a profit and contribute to the development of the national economy, but this performance has not been achieved. In [29] as the Minister of SOE stated that in 2015 there were 18 state-owned enterprises which still suffered losses, with a total loss of Rp. 5.8 trillion. The amount compared to 2014 was a decrease, because there were 27 companies that suffered losses totaling Rp 10.2 trillion. In [29] also stated that in 2015 the net profit of BUMN had decreased compared to 2014. Profit from BUMN in 2015 decreased from Rp 159 trillion in 2014 to Rp 150 trillion in 2015 [26].

The results of research conducted by $[3,5-6,9,12-13,15-16,21-$ $22,28]$ stated that management performance can be influenced by a management control system applied to a company.

Besides the results of research conducted by $[4,7,14,17-19,23]$ stated that leadership style influences managerial performance. Based on the above background, the author is interested in conducting similar research with the title "The Effect of Management Control Systems and Leadership Style on Managerial Performance (Empirical Study on State-Owned Enterprises in Bandung City)."

\section{Literature Review}

"The management control system is a system that consists of several interconnected systems namely programming, budgeting, accountability and performance reporting and an authority delegation system to help the management of an organization or compa- ny to achieve its goals through certain strategies efficiently and effectively" [20].

According to [25], the construct of the management control system has several dimensions namely:

1. Performance evaluation is an evaluation system that helps encourage employee development and motivates employee performance.

2. Compensation is an award given by a company to employees based on their performance.

3. Communication is the ability of managers to communicate the vision, mission and goals of the company to stakeholders (stakeholders) honestly, openly and systematically.

4. Conflict resolution is the ability of managers to anticipate and find solutions to conflicts that arise in the company.

5. Commitment is the ability of managers to obtain commitments from all employees to realize the company's vision, mission and goals.

6. Product and market policies are the company's ability to produce goods or services that can meet needs and provide satisfaction to customers.

"Leadership style is a method used by a leader in influencing the behaviour of others. From this style, the benefits can be used to be used as a guide for leaders in leading subordinates or their followers" [24].

In [1] developed an indicator of transformational leadership style consisting of two types namely:

1. Followers' Belief (Follower Belief) consists of inspiration, admiration, empowerment

2. Attributes of Leader Behaviour Attributes consists of show empathy, explain the mission interestingly, show confidence, improve the image of the leader, provide opportunities for success 
In $[2,11]$ define managerial performance as the performance of individual organizational members in managerial activities, including: planning, investigating, coordinating, evaluating, supervising, staffing, negotiating and representing.

\section{Theoretical Framework and Hypothesis Development}

In $[3,15-16,21-22,28]$ shows that the management control system in the company can encourage managerial performance so as to improve the company's performance in generating profits. Therefore, the authors take the following hypothesis:

H1: Management control systems have a positive impact on managerial performance.

In $[7-8,10,17,23-24]$ shows that the right leadership style can motivate employees to work productively, so as to produce high managerial performance so that company performance can also be achieved. Therefore, the authors take the following hypothesis: $\mathrm{H} 2$ : Leadership style has a positive effect on managerial performance.

In $[12-13,15,21,23,25]$ that the control system and leadership style together can influence managerial performance that supports the company's performance. Therefore, the authors take the following hypothesis:

H3: Management control systems and leadership styles have a positive effect on managerial performance.

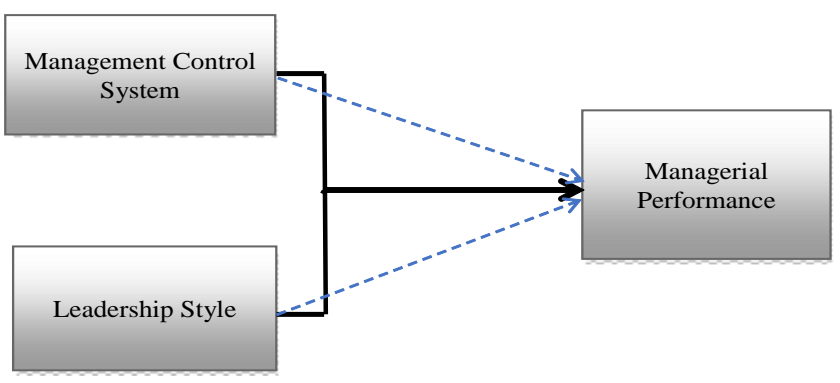

Fig. 1: Theoretical Framework

\section{Method and Finding}

\subsection{Method}

The method used in this study is an explanatory method. The population in this study was all employees who worked at managerial level in state-owned companies in Bandung. The sampling method used is purposive sampling method. Purposive sampling is a sample determination technique with certain considerations. The instrument used in this study is a questionnaire. The management control system variable questionnaire (X1) was adopted from [25] with a total of 25 items. The leadership style variable questionnaire (X2) was adopted from [1] with a total of 33 statements. The dependent variable questionnaire is managerial performance variable $(\mathrm{Y})$ adopted from [11] with a total of 9 items. The validity and reliability of the questionnaire data has been tested and also tested as follows: classic assumption test, normality test, multicollinearity test, and heteroscedasticity test. The relationship between variables is seen with multiple regression analysis and hypothesis simultaneous testing ( $\mathrm{F}$ test).

\subsection{Finding}

Based on the interval score, the respondent's perception of the Management Control System Assessment is already good in its implementation and the respondent's perception that employees believe in their leaders and their leaders have attributes as leaders. Based on the interval score, the respondent's perception can be concluded that managerial performance in state-owned enterprises in manufacturing in Bandung is considered good.

Table 1: Coefficient of Determination

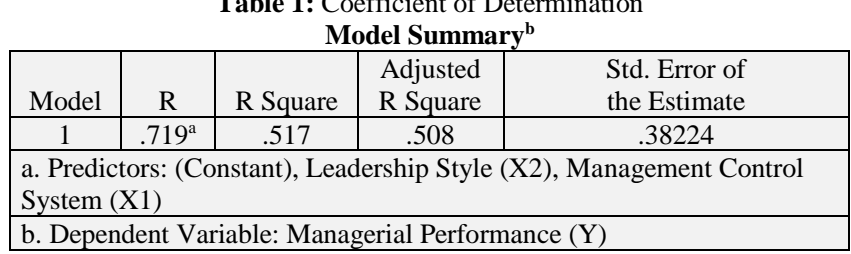

Table 1 shows that the results of the correlation between management control systems and leadership style with managerial performance is 0.719 , it can be concluded that the relationship between management control systems and leadership style with managerial performance is in the strong category. As for the determinant coefficient, the result is 0.517 . This shows that the management control system and leadership style contribute $51.7 \%$ in influencing managerial performance, and the remaining $48.3 \%$ is influenced by other factors not examined in this study.

Table 2: ANOVA (F test) Results

\begin{tabular}{|l|c|c|c|c|c|c|}
\hline \multicolumn{7}{|c|}{ ANOVA $^{\mathrm{a}}$} \\
\hline \multicolumn{2}{|c|}{ Model } & $\begin{array}{c}\text { Sum of } \\
\text { Squares }\end{array}$ & df & $\begin{array}{c}\text { Mean } \\
\text { Square }\end{array}$ & F & Sig. \\
\hline \multirow{2}{*}{1} & Regression & 16.556 & 2 & 8.278 & 56.657 & $.000^{\mathrm{b}}$ \\
\cline { 2 - 7 } & Residual & 15.487 & 106 & .146 & & \\
\cline { 2 - 7 } & Total & 32.043 & 108 & & & \\
\hline
\end{tabular}

Table 2 shows the Fcount value of 56,657 with a probability (significance value) of 0,000 . The hypothesis set can be tested by comparing between Fcounts and Ftable values. From table F obtained the value of Ftable with df $1=2$ and df $2=109-2-1=106$ by 3.082. The Fcount value obtained is 56,657 greater than Ftable equal to 3,082 . The significance value in the $\mathrm{F}$ test is 0,000 , where the significance value is smaller than 0.05 , so it can be concluded that $\mathrm{HO}$ is rejected and $\mathrm{Ha}$ is accepted. This means that the management control system and leadership style simultaneously influence managerial performance.

Table 3: Multiple Linear Regression Results

\begin{tabular}{|c|c|c|c|c|c|c|c|c|c|}
\hline \multicolumn{10}{|c|}{ Coefficients $^{\mathrm{a}}$} \\
\hline \multirow{2}{*}{\multicolumn{2}{|c|}{ Model }} & \multicolumn{2}{|c|}{ Unstandardized Coefficients } & \multirow{2}{*}{$\begin{array}{c}\text { Standardized Coefficients } \\
\text { Beta }\end{array}$} & \multirow[b]{2}{*}{$\mathrm{t}$} & \multirow[b]{2}{*}{ Sig. } & \multicolumn{3}{|c|}{ Correlations } \\
\hline & & $\mathrm{B}$ & Std. Error & & & & Zero-Order & Partial & Part \\
\hline \multirow[t]{3}{*}{1} & (Constant) & -.211 & .319 & & -.663 & .509 & & & \\
\hline & Management Control System (X1) & .422 & .091 & .374 & 4.660 & .000 & .614 & .412 & .315 \\
\hline & Leadership Style (X2) & .598 & .108 & .445 & 5.544 & .000 & .646 & .474 & .374 \\
\hline
\end{tabular}

a. Dependent Variable: Managerial Performance (Y) 
From Table 3, the multiple regression equation obtained for the research data used is as follows: $\mathrm{Y}=-0,211+0,422 \mathrm{X} 1+0,598$ $\mathrm{X} 2$.

Table 3 shows the tcount of the management control system variable (X1) obtained at 4.660 with a significance value of 0.000 . The results of the calculation of the t-test statistic obtained showed that the t-count for the independent variable management control system $(\mathrm{X} 1)$ was greater than the $\mathrm{t}$-table value $(\mathrm{t}=4.660>1.9826)$. The $\mathrm{t}$ test statistic value obtained was in the reject area $\mathrm{H} 0$, so the $\mathrm{HO}$ test results were rejected. This result is also indicated by the significance value of the statistical test (p-value) $(0,000)$ smaller than the acceptable error rate of $5 \%$. The test results at a $95 \%$ confidence level can be concluded that there is a significant effect of the management control system on managerial performance. Table 3 also shows the tcount of leadership style variables (X2) obtained at 5.544 with a significance value of 0.000 . The results of the calculation of the t-test statistic obtained showed that the tcount for the independent variable leadership style (X2) was greater than the $\mathrm{t}$-table value $(\mathrm{t}=5.544>1.9826)$. The $\mathrm{t}$ test statistic value obtained was in the reject area $\mathrm{H} 0$, so the $\mathrm{H} 0$ test results were rejected. This result is also indicated by the significance value of the statistical test (p-value) $(0,000)$ smaller than the acceptable error rate of $5 \%$. The test results at $95 \%$ confidence level can be concluded that there is a significant influence of leadership style on managerial performance.

\section{Conclusion}

Management control systems in state-owned enterprises manufacturing in Bandung are considered to be good in their implementation. Management control systems affect managerial performance, meaning that variations in management control systems can explain variations in managerial performance. The better management control system will be followed by increased managerial performance. The leadership style applied to state-owned enterprises in manufacturing in the city of Bandung is a transformational leadership style. Leadership style influences managerial performance, meaning that a variety of leadership styles can explain variations in managerial performance. The more transformed leadership style will be followed by increased managerial performance. Managerial performance of state-owned enterprises in manufacturing in the city of Bandung is considered good in its implementation. Control System Management and leadership style simultaneously influence managerial performance.

\section{References}

[1] Behling, O. \& McFillen, J.M. (1996). A Syncretical Model of Charismatic/Tranformational Leadership. Journal of Group and Organization Management, 21(2), 163-191.

[2] Christina, V. (2010). Pengaruh Individual Differences terhadap Sistem Informasi Akuntansi Manajemen dan Dampaknya Bagi Kinerja Manajerial (Penelitian pada Industri Manufaktur yang Terdaftar di BEI). Phd thesis, Universitas Padjajaran.

[3] Dermawan, W.D. (2013). Pengaruh Sistem Pengendalian Manajemen Terhadap Kinerja Manajerial (Studi Kasus pada PT. Telekomunikasi Indonesia, Tbk.). Universitas Widyatama.

[4] Elviani, S. (2010). Pengaruh Motivasi Kerja, Gaya Kepemimpinan, Komunikasi dan Budaya Organisasi Terhadap Kinerja Manajerial Dengan Kepuasan Kerja Pegawai Sebagai Variabel Intervening (Studi Kasus pada Universitas Islam Sumatera Utara). Thesis, Universitas Sumatera Utara.

[5] Embrianto, P.A., Ni Luh, G.E.S. \& Ni Kadek, S. (2016). Pengaruh Partisipasi Anggaran, Gaya Kepemimpinan, Sistem Pengendalian Manajemen dan Total Quality Management Terhadap Kinerja Karyawan dengan Locus of Control Sebagai Variabel Moderating (Studi Pada Dinas Pendapatan Kabupaten Buleleng). Jurnal Ilmiah Mahasiswa Akuntansi S1 Universitas Pendidikan Ganesha, 6(3), 111.
[6] Fadjar, A. \& Muslim, A.K. (2012). Pengaruh Sistem Pengendalian Manajemen dan Budaya Organisasi Terhadap Tingkat Kesehatan Perusahaan. Proceedings of the Seminar Nasional Akuntansi dan Bisnis, pp 564-569.

[7] Ginanjar, M. (2013). Pengaruh Gaya Kepemimpinan Terhadap Hubungan Antara Partisipasi Anggaran dan Kinerja Manajerial (Studi Kasus pada Bank Kantor Cabang di Bandung). Universitas Widyatama.

[8] Halim, A., Achmad, T. \& Muh., F.H. (2000). Sistem Pengendalian Manajemen. Akademi Manajemen Perusahaan YKPN.

[9] Herawaty, N., Susfa, Y. \& Gowon, M. (2009). Pengaruh Struktur Pengendalian Manajemen dan Proses Pengendalian Manajemen Terhadap Kinerja Perbankan Kota Jambi. Jurnal Penelitian Universitas Jambi Seri Humaniora, 11(2), 31-36.

[10] Kartono, K. (2008). Pemimpin dan Kepemimpinan: Apakah Pemimpin Abnormal Itu? PT. Raja Grafindo Persada.

[11] Mahoney, T.A, Jerdee, T.H. \& Carroll, S.J. (1963). Development of Managerial Performance: A Research Approach. South Western Publishing Co.

[12] Marlita, S. (2013). Pengaruh Sistem Pengendalian Manajemen dan Gaya Kepemipinan Terhadap Kinerja Manajerial pada PT. Bank Rakyat Indonesia (Persero), Tbk. Cabang Cimahi. Universitas Kristen Maranatha.

[13] Nguyen, T.T., Lokman, M., Lanita, W., Vincent, K.C. (2016) Effect of Transformational Leadership Style and Management Control System on Managerial Performance. Journal of Business Research, 70, 202-213.

[14] Nurjanah. (2008). Pengaruh Gaya Kepemimpinan dan Budaya Organisasi Terhadap Komitmen Organisasi dalam Meningkatkan Kinerja Karyawan. Tesis, Fakultas Manajemen Universitas Diponegoro.

[15] Porporato, M. (2006). Impact of Management Control System Intensity of Use on Joint Venture's Performance: An Empirical Assessment. Journal of Management Contol System, 21, 512-562.

[16] Pratama, M.I. (2013). Pengaruh Sistem Pengendalian Manajemen terhadap Kinerja Manajerial dengan Kepemimpinan sebagai Variabel Moderasi (Studi Kasus pada PT. Sagaya Inti Utama) Universitas Kristen Maranatha.

[17] Purnama, A.H. (2015). Pengaruh Partisipasi Anggaran dan Gaya Kepemimpinan Terhadap Kinerja Manajerial Studi Kasus pada PT. Indosat Tbk. Bandung. Universitas Widyatama.

[18] Riaz, A. \& Haider, M.H..(2010). Role of Transformational and Transactional Leadership on Job Satisfaction and Career Satisfaction. Journal of Business and Economic Horizons, 1, 29-38.

[19] Riyadi, S. (2011). Pengaruh Kompensasi Finansial, Gaya Kepemimpinan dan Motivasi Kerja Terhadap Kinerja Karyawan pada Perusahaan Manufaktur di Jawa Timur. Jurnal Manajemen dan Kewirausahaan, 13(1),40-45.

[20] Sukarno, E. (2002). Sistem Pengendalian Manajemen: Suatu Pendekatan Praktis. PT. Gramedia Pustaka Utama.

[21] Suprobo, W.A. (2014). Pengaruh Sistem Pengendalian Manajemen (SPM) Terhadap Kinerja Karyawan dengan Inovasi Sebagai Variabel Intervening pada Usaha Mikro Kecil Menengah (UMKM) Sektor Kuliner Wilayah Banyuwangi. Universitas Jember Kalimantan.

[22] Susanti, T. (2013). Peranan Pengendalian Manajemen Terhadap Kinerja Manajerial dalam Pengelolaan Kredit pada PT. BPR Jember Lestari Provinsi Jawa Timur (Studi Kasus PT. BPR Jember Lestari). Universitas Jember.

[23] Syafriadi. (2015). Pengaruh Partisipasi Anggaran, Gaya Kepemimpinan dan Komitmen Organisasi Terhadap Kinerja Manajerial (Studi Kasus Pada Universitas Pembangunan Pancabudi). Jurnal Ilmiah Integritas, 1(4), 71-85.

[24] Thoha, M. (1983). Perilaku Organisasi: Konsep Dasar dan Aplikasinya. PT. Raja Grafindo Persada.

[25] Gani, L. \& Jermias, J. (2009). The Effects of Strategy Management Control System Misfits on Firm Performance. https://papers.ssrn.com/sol3/papers.cfm?abstract_id=1531266.

[26] Peraturan Menteri BUMN. http://jdih.bumn.go.id/lihat/PER10/MBU/07/2015.

[27] Undang-Undang No. 19 Tahun http://www.bpkp.go.id/uu/filedownload/2/40/264.bpkp.

[28] Lekampotessy, J.E. (2012). Peran Sistem Pengendalian Manajemen dalam Meningkatkan Kinerja Perusahaan: Analisis Kontinjensi dan Resource-Based View. Universitas Diponegoro.

[29] Ferida, K. (2016). http://indonesianindustry.com/menteri-rini-di2015-bumn-cetak-laba-bersih-rp150-triliun-2. 